\title{
AN INTRODUCTORY ARTICLE ON THE CONCEPT OF PROGRAMME DEVELOPMENT IN Physiotherapy TRAINING
}

\begin{abstract}
The move to an outcomes-based education and training system in South Africa presents higher education and training institutions with a challenge to review their curricula and to adapt to changes brought about by the new education and health care dispensations. Key aspects of the move to outcomesbased education and training as contained in the South African Qualifications Authority (SAQA) Act, information regarding the National Qualifications Framework (NQF) and other matters informing curriculum review are addressed. The Department of \section{VILOEN MJ, D.SOC.SC. (UOFS) ${ }^{2}$ BEZUIDENHOUT MJ, B.A., DIPL. IN TERTIARY ED. (UOFS) ${ }^{3}$}

KRAUSE MW, MSC PHYSIOTHERAPY' (UOFS)

${ }_{2}^{1}$ Faculty of Health Sciences, University of the Orange Free State ${ }_{3}^{2}$ Faculty of Health Sciences, University of the Orange Free State ${ }^{3}$ Faculty of Health Sciences, University of the Orange Free State Physiotherapy of the University of the Orange Free State has just completed the first phase of restructuring its education and training programme in order to submit the qualification for registration on the NQF The rationale behind the shift to an outcomes-based, student-centred curriculum and the key features of the programme are briefly discussed, as this is the first step towards the registration of unit standards/qualifications, a process which all education and training institutions will have to embark upon soon.
\end{abstract}

KEY CONCEPTS: OUTCOMES-BASED EDUCATION AND TRAINING, CURRICULUM REVIEW, PHYSIOTHERAPY PROGRAMME, CRITICAL AND SPECIFIC OUTCOMES

\section{INTRODUCTION}

As the world gallops to the new millennium, higher education is becoming increasingly more complex, with institutions facing many new challenges. The pressure is on to complete new programmes with standards that will satisfy the criteria for registration, taking cognisance of extremely important issues regarding new policy developments such as the SAQA (South African Qualifications Authority) Bill, the NQF (National Qualifications Framework), the Higher Education Act, and the move towards an emphasis on primary health care in the country; a paradigm shift from teaching to learning; new delivery modes; the urge for quality promotion and quality assurance; disadvantaged students; capacity

\section{CORRESPONDENCE:}

Prof. M.W. Krause

Head: Department of Physiotherapy School of Allied Health Professions Faculty of Health Sciences University of the Orange Free State P O Box 339 BLOEMFONTEIN 9300 Tel (051) 401-3290(w) (05l) 436-6669 (h) Fax (051) 401-3304 building and public accountability, to name but some. Physiotherapy training centres are experiencing similar pressures and realise the urgent need to revise the traditional South African Physiotherapy curriculum.

This article aims at applying the regulations of the SAQA Act (RSA 1998) in a physiotherapy curriculum review process. It is important for educators to understand the Department of Education's new 'paradigm' of outcomes-based education and training (OBET) and become equipped with the knowledge and skills required to design programmes demonstrating OBET principles in order to be able to register qualifications which comply with SAQA conditions.

\section{SAQA AND THE NQF}

The idea of a National Qualifications Framework arose from debates, research and policy formation for education and training in the early 1990s (SAQA 1997). It was developed out of initiatives involving representatives from labour, management, government and providers of education and training, and finally agreement was reached on the concept of transparent national standards, understood as specific descriptions of learning achievements agreed upon by all major stakeholders. These standards are to be housed within a qualifications framework designed to promote lifelong learning, integrate education and training, recognise learning gained outside of formal institutions and allow for flexible programmes, credits and qualifications. The draft of the NQF Bill was passed into law as the SAQA Act (Act 58 of 1995).

The objective of the NQF, as laid out in the Act, is to create an integrated national framework for learning. Enhancing quality in education and training, access, mobility and progression are key objectives, and it is reiterated that attention should be given to the speedy redress of past discrimination in education, training and employment. Through these objectives, the NQF envisages to contribute to the full personal development of each learner and the social and economic development of the nation at large (SAQA 1997).

The NQF is an eight-level framework established to give recognition to general education and training (GET) (level 1 and lower), further educaton and training (FET) (levels 2 to 4 ), and higher 
education and training (HET) (levels 5 to 8 ). The levels pertaining to the HET band, including university education and training, are (RSA 1998): NQF level 5: diplomas; occupational certificates; NQF level 6: first degrees; higher diplomas; NQF level 7: higher degrees; professional qualifications; NQF level 8: doctorates and further research degrees.

SAQA is in the process of refining level descriptors. For the purpose of this article suffice it to say that it sometimes may be difficult to draw distinctions between levels, and that the guidelines SAQA has provided, should be studied carefully. Writers of standards need to consider the intention behind the standard, that is, the occupation, activity, or learning process that a learner who has achieved the outcomes required for the standard, is qualified to undertake.

The South African Qualifications Authority comprises a chairperson and members nominated from education, labour, business, universities, technikons, colleges, adult basic education and training, the teaching profession and special education needs. Its functions include (RSA 1998):

- The development of the NQF: policies, guidelines and criteria for registration and accreditation.

- The implementation of the NQF: registration, accreditation and assignment of functions to the bodies satisfying the requirements (registration of standards/ qualifications).

- Advising the Ministers of Education and Labour.

- Consulting with all relevant parties.

\section{OUTCOMES-BASED EDUCATION AND TRAINING (OBET)}

The move to outcomes-based education and training may present educators with a challenge big enough to be called a "paradigm shift" (Lubisi et al. 1997), but the concept is not entirely new. Good teachers, it is argued, have always measured the value of their instruction in terms of what the learners have gained, that is, the outcome of the teachinglearning process.

Curriculum development for outcomes-based education and training will take as point of departure the proposed results of the learning, rather than the content that has to be mastered. In contrast to a content-based education and training programme (with a focus on objectives), the emphasis in outcomesbased education and training is on the outcome (result) of the process, i.e. the competence (interaction between knowledge, skills and attitudes) of the learner as a result of the learning activity. If correctly applied, the focus on outcomes encourages the development of flexible, integrated and relevant instructional programmes. Differentiation is made among different types of outcomes, which should be taken cognisance of in any instructional programme (Nel \& Bezuidenhout 1998).

\section{Critical outcomes}

The critical cross-field education and training outcomes describe the proposed results of education and training in the broader sense of the word. These are generic and people-directed skills and competencies, that extend across curricula. They should be seen as principles and as such they should direct the education and training processes, as well as the development of learning programmes and material, that is, these outcomes should inform the specific outcomes. (RSA 1998).

Regulation 7(3) of the SAQA Act (RSA 1998) stipulates a number of critical outcomes which boil down to:

a) identifying and solving problems and employing critical and creative thinking;

b) working in a team/group;

c) organising and managing oneself and one's activities;

d) collecting, analysing organising and critically evaluating information;

e) communicating effectively (orally and in writing);

f) using science and technology effectively and critically;

g) demonstrating an understanding of the world as a set of related systems by recognising that problem-solving contexts do not exist in isolation;

h) contributing to the full personal development of each learner and the social and economic development of the society at large, by making individuals aware of the importance of: i. a variety of strategies to learn more effectively;

ii. participating as responsible citizens in the life of local, national and global communities;

iii.being culturally and aesthetically sensitive across a range of social contexts;

iv. exploring education and career opportunities; and

v. developing entrepreneurial opportunities.

\section{Specific outcomes}

Specific outcomes are context-specific. They endorse critical outcomes, but are formulated within the context of a specific programme, that is, the context within which they are to be demonstrated. They describe the competence learners should have at their disposal in special areas of learning at specific levels. These outcomes serve as basis for evaluating learners' progress, therefore details of the level of complexity, scope and learning context should be included in specific outcomes (Lubisi et al. 1997).

\section{Vocational / professional outcomes}

The vocational outcomes empower a specific group for a specific career. In the case of a professional degree they constitute the profile of the graduate; therefore these outcomes, for example, will include the conditions set forth by the particular professional board, such as themes related to professional practice and conduct.

\section{AN OUTCOMES-BASED PHYSIOTHERAPY CURRICULUM}

The Department of Physiotherapy of the University of the Orange Free State during 1998 embarked upon a series of development activities which resulted in an innovative physiotherapy curriculum, designed within the broad framework set out in the SAQA Act.

The concept of outcomes and their measurement is also becoming an essential feature of health care delivery. In the development of vocational (professional) qualifications the emphasis has been transferred from input and content of education to its outcomes, particularly as a means of achieving and recording specific levels of competence. 
This Department of Physiotherapy fully and enthusiastically supports the move to innovative education and training strategies as described. Due to the changes in physiotherapy practice and the environment in which physiotherapists work, they are increasingly required to operate as independent practitioners and they are committed to evidencebased practice. They have to evaluate and reflect upon their practice and initiate and respond to change. Therefore it is the duty and responsibility of education and training institutions to prepare the future practitioners accordingly. The training of a physiotherapist must encompass multi-disciplinary and interprofessional education and training with outcomes that are strongly related to high-level skills and aptitudes.

\section{THE DEPARTMENT OF PHYSIOTHERAPY, UOFS}

The Department of Physiotherapy of the UOFS up to now has followed a traditional instructional mode. Currently a Bachelor of Science degree with honours status is offered, based on a sequential four-year course in a single discipline.

With the new curriculum a movement to more problem-based and resourcebased education and training is envisaged. ln revising the programme the general aims and outcomes have been formulated and the staff members are now in the process of defining specific outcomes, in order to select appropriate contents, compile workbooks and lay a foundation for evaluation. Detail concerning the level of complexity, scope and learning context included in the formulation of specific outcomes is crucial if assessment is to be transparent, fair and effective (Lubisi et al. 1997).

\section{The curriculum review process}

In order to put ourselves in the picture as far as educational reform is concerned, the lecturers of the Department attended every possible development opportunity, for example the staff development sessions offered in the Faculty of Health Sciences, and studied literature on curriculum review, primary health care, outcomes-based education and training, and new trends in education, not only in South Africa, but world-wide. The principles underlying the SAQA Act, it became clear, represent global changes in education and training and thus we realised that if we wanted to still be relevant and provide our physiotherapy students with relevant and applicable education and training, the UOFS physiotherapy curriculum would have to be reviewed and adapted or changed completely.

The lecturers in the Department, with the assistance of staff from the Division of Educational Development in the Faculty, held a workshop to decide on a modus operandi. A SWOT analysis was done (perceived strengths and weaknesses in the current curriculum were weighed up, opportunities curriculum review would afford, were identified, and possible threats the whole process of educational innovation and renewal might hold, were pointed out). Following a session during which OBET, SAQA, the NQF and other relevant information were discussed, the Department embarked on the process of compiling an innovative physiotherapy programme

\section{Outcomes of an OBET physiotherapy programme}

The professional physiotherapist, as defined by this Department, is a member of the health care profession who emphasises the use of physical approaches in the promotion, maintenance and restoration of an individual's physical, psychological and social well-being.

The core skills used to achieve this are manual therapy, therapeutic exercises and the application of electrophysical modalities. Through assessment, problemsolving clinical reasoning, treatment and education individuals' specific needs are addressed in order to optimise their functional ability and potential.

The critical outcomes, which are generic and not context-bound, as specified in the SAQA Act (South Africa 1998), will be pursued throughout the four-year Physiotherapy programme.

In the UOFS Physiotherapy Department's striving to deliver physiotherapists of high quality, who are relevantly trained to address the health needs of the people, and who will be life-long learners, and at the same time satisfy the requirements of the SAQA and the $\mathrm{NQF}$, the following specific outcomes have been formulated, and are considered a synopsis of outcomes to be developed during the respective stages of physiotherapy students' education and training:

\section{Knowledge}

The student qualifying as physiotherapist from the Department must be able to

- demonstrate a basic knowledge of normal human development, structures, pathological conditions;

- apply the principles in manual therapeutic exercises and the application of electro-physical modalities (as understood in preventative, therapeutic and rehabilitative promative health);

- demonstrate fundamental and core knowledge required to qualify as physiotherapist, as well as knowledge obtained through elective rotations;

- evaluate and assess health care sciences and services, by applying the principles of health sciences.

\section{Skills}

The student qualifying as physiotherapist from the Department must be able to

- demonstrate the necessary clinical skills to be able to practise preventative, therapeutic, rehabilitative and promotive physiotherapy;

- demonstrate relevant diagnostic skills;

- communicate scientifically and professionally;

- demonstrate problem-solving skills and be able to work in a group;

- demonstrate technological and other appropriate physiotherapeutic skills;

- demonstrate knowledge and skills pertaining to health care and social services that can be used in response to the varied needs of the patient.

\section{Practice and health care service deliv- ering}

The student qualifying as physiotherapist from the Department must be able to

- demonstrate sound knowledge of professional practice in the public and private sectors;

- demonstrate knowledge about the health care policy of the country, and global trends and issues in health care;

- work as a member of the multi-professional health team and demonstrate knowledge of the roles of the other members of the team; 
- maintain the personal, ethical and professional standards applicable to physiotherapy;

- demonstrate knowledge of the essential acts and regulations concerning the health care dispensation, labour system and other relevant areas that have a bearing on physiotherapy as profession and in practice.

\section{Attitudes}

The student qualifying as physiotherapist from the Department must be able to

- demonstrate a holistic approach to patients and in the social milieu;

- demonstrate a positive approach to health care services at all the levels;

- demonstrate a community-orientated and primary health care approach in service rendering;

- demonstrate understanding of and a sensitivity for transcultural issues and norms;

- embark on activities related to lifelong learning;

- show insight into his/her limitations regarding knowledge and skills and the necessity of becoming a life-long learner.

Critreria to assess and validate these outcomes must be developed. These should subscribe to the principles of formative and summative evaluation.

Major changes in the South African education and training and health care dispensations, and the need to conform to the global shift in emphasis from content-based and teacher-directed curricula to outcomes-based and learner-directed curricula represent the driving force behind the revised framework of this Department. With this new education and training programme the Department hopes to make a major shift from "old" curriculum elements to innovative ideas and approaches, as contained in Curriculum 2005 (in Bitzer 1997): Table 1

\section{CONCLUSION}

The Green Paper (Department of Education 1998) states that in the NQF the emphasis will be on high quality programmes and internationally recognised qualifications which integrate education and training, preparing learners for lifelong learning as well as a career/profes-

TABLE 1: "OLD" AND "NEW" CURRICULUM ELEMENTS

\begin{tabular}{|l|l|}
\hline "Old" curriculum & "New" curriculum \\
\hline Passive learners & Active learners; learner involvement \\
\hline Examination driven & Continuing evaluation \\
\hline Rote (superficial) learning & $\begin{array}{l}\text { Critical thinking, reflection, } \\
\text { active learning }\end{array}$ \\
\hline Content-based & $\begin{array}{l}\text { Outcomes-based, } \\
\text { integrated knowledge, relevance }\end{array}$ \\
\hline $\begin{array}{l}\text { Lecturer-centred and } \\
\text { text-book bound }\end{array}$ & $\begin{array}{l}\text { Learner-centred; learning } \\
\text { facilitation; group and team work }\end{array}$ \\
\hline $\begin{array}{l}\text { Syllabus-bound, rigid and } \\
\text { non-negotiable }\end{array}$ & $\begin{array}{l}\text { Learning programmes serve as } \\
\text { guide for innovative and } \\
\text { creative learning }\end{array}$ \\
\hline $\begin{array}{l}\text { Lecturer responsible for } \\
\text { students' learning }\end{array}$ & $\begin{array}{l}\text { Learner responsible for learning, } \\
\text { motivated by continuing evaluation } \\
\text { and feedback }\end{array}$ \\
\hline Emphasis on achievements & $\begin{array}{l}\text { Emphasis on outcomes } \\
\text { (what the learner knows, } \\
\text { can do and understands) }\end{array}$ \\
\hline
\end{tabular}

sion. This is to be attained through outcomes-based education and training, where the premise is that more attention should be paid to what emerges at the end of the process of teaching and learning than to the inputs.

There are numerous questions which cannot be addressed in this article as this field is extremely comprehensive, however, the underlying principles of educational transformation, which have to be taken cognisance of when qualifications (programmes) are submitted for registration to SAQA and the NQF, ought to be mentioned: Equity and equality, democratisation, development, quality effectiveness, academic freedom, institutional autonomy, and public accountability (Nel \& Bezuidenhout 1998).

Another important aspect of programme design which has not been touched upon here, is the matter of credits required for a qualification to be registered. This is linked to notional learning hours, and is a topic which warrants a discussion of its own, as are the criteria for the registration of qualifications, as spelt out in the Act, and the bodies involved with SAQA, such as the Standards Generating (SGBs) and National Standards Bodies (NSBs).

\section{REFERENCES}

Bitzer EM. 1997. Programbeplanning en die NKR. Unpublished working document. Academic Development Bureau, UOFS

Department of Education. 1998. Green Paper on Further Education and Training: Preparing for the Twenty-first Century through Education, Training and Work. Department of Education, Pretoria.

Lubisi C, Wedekind V, Parker B \& Gultig J. 1997. Understanding outcomes-based education: Knowledge, curriculum and assessment in South Africa. SAIDE, Braamfontein.

Nel MM \& Bezuidenhout MJ. 1998. Programontwikkeling / Programme Development. Unpublished report. Division of Educational Development, Faculty of Health Sciences, UOFS.

RSA 1998. South African Qualifications Authority: regulations under the South African Qualifications Authority Act, 1995 (Act No. 58 of 1995). Government Gazette, 18787, 28 March.

SAQA. 1997. The emergence of the NQF and SAQA. SAQA Bulletin 1(1): 2 - 18 